\title{
Dating of streamwater using tritium in a post nuclear bomb pulse world: continuous variation of mean transit time with streamflow
}

\author{
U. Morgenstern ${ }^{1}$, M. K. Stewart ${ }^{2}$, and R. Stenger ${ }^{3}$ \\ ${ }^{1}$ GNS Science, P.O. Box 30 368, Lower Hutt 5040, New Zealand \\ ${ }^{2}$ Aquifer Dynamics \& GNS Science, P.O. Box 30 368, Lower Hutt 5040, New Zealand \\ ${ }^{3}$ Lincoln Ventures Ltd. (LVL), Private Bag 3062, Hamilton 3214, New Zealand
}

Received: 25 June 2010 - Published in Hydrol. Earth Syst. Sci. Discuss.: 20 July 2010

Revised: 7 October 2010 - Accepted: 1 November 2010 - Published: 18 November 2010

\begin{abstract}
Tritium measurements of streamwater draining the Toenepi catchment, a small dairy farming area in Waikato, New Zealand, have shown that the mean transit time of the water varies with the flow rate of the stream. Mean transit times through the catchment are 2-5 years during high baseflow conditions in winter, increasing to $30-40$ years as baseflow decreases in summer, and then dramatically older water during drought conditions with mean transit time of more than 100 years. Older water is gained in the lower reaches of the stream, compared to younger water in the headwater catchment. The groundwater store supplying baseflow was estimated from the mean transit time and average baseflow to be $15.4 \times 10^{6} \mathrm{~m}^{3}$ of water, about $1 \mathrm{~m}$ water equivalent over the catchment and 2.3 times total annual streamflow. Nitrate is relatively high at higher flow rates in winter, but is low at times of low flow with old water. This reflects both lower nitrate loading in the catchment several decades ago as compared to current intensive dairy farming, and denitrification processes occurring in the older groundwater. Silica, leached from the aquifer material and accumulating in the water in proportion to contact time, is high at times of low streamflow with old water. There was a good correlation between silica concentration and streamwater age, which potentially allows silica concentrations to be used as a proxy for age when calibrated by tritium measurements. This study shows that tritium dating of stream water is possible with single tritium measurements now that bomb-test tritium has effectively disappeared from hydrological systems in New Zealand, without the need for time-series data.
\end{abstract}

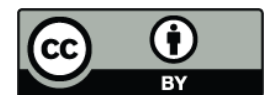

Correspondence to: U. Morgenstern (u.morgenstern@gns.cri.nz)

\section{Introduction}

The source of the baseflow component in streams is usually groundwater. This truism and the fact that baseflow is often the dominant component of streamflow (Hewlett and Hibbert, 1967) shows that in order to understand the quantity and quality of streamflow, we need to understand the dynamics and volumes of the underlying groundwater resource feeding the stream.

We still have limited understanding of the dynamics of the groundwater component that is transmitting much of the water from rainfall to streams. According to the dynamics of these underlying groundwaters, the streams' response is modulated in flow and strongly damped and delayed in hydrochemical composition compared to rainfall (Kirchner, 2003). A fundamental parameter of the groundwater dynamics is the age distribution of the groundwater. Accurate groundwater ages can greatly improve our conceptual understanding of streamflow generation. We show with data from the small Toenepi catchment in New Zealand how the age of the streamwater illumines these dynamics.

Accurate groundwater ages can significantly improve conceptual flow models and allow direct calibration of numerical flow models (e.g. Bethke and Johnson, 2008) for detailed understanding of the groundwater resource, of water flow paths that describe the pathway along individual flow lines for certain points in the catchment, and delays in transporting contaminants from the land into streams. However, this paper does not aim to establish a detailed groundwater flow model for the Toenepi catchment.

Rather, this paper focuses on the fundamental parameters of groundwater models, the conceptual flow model and the mean transit time and volume of the water, derived from the tritium signatures in the baseflow of the stream at the

Published by Copernicus Publications on behalf of the European Geosciences Union. 
catchment outflow. The resultant mean transit times and groundwater volumes therefore provide measures of groundwater parameters integrated over the whole catchment. Water transit time, and amount of water stored in the catchment, rather than only fluxes, are crucial for water management issues and understanding the response of the stream to environmental change and pollution.

Many previous studies have used environmental isotopic or chemical tracers to determine transit time distributions and mean transit times for catchments (references in McGuire and McDonnell, 2006). Often these studies derive a single mean transit time to characterise the streamflow (or sometimes only the baseflow), although it is intuitively likely for example that the mean transit times of high flows will be different from those of low flows in many catchments. It has been difficult to probe the likely different mean transit times at different parts of the hydrograph with the most-used methods (i.e. variations of stable isotopes and chemicals). However, other studies using tritium have been able to look at several components in streamflow and show that their mean transit times can be very different (Maloszewski and Zuber, 1982; references in Stewart et al., 2010). This work reveals a continuous variation of mean transit time with streamflow. And, in particular, it establishes the possibility and importance of being able to estimate ages from individual tritium measurements for given streamflow rates.

This paper represents one of the early detailed results of stream water age derived from tritium data in the post bomb-test world of the Southern Hemisphere (McGlynn et al., 2003; Stewart et al., 2007; Stewart and Fahey, 2010; Morgenstern, 2007). It gives a preview of what will also become possible in the Northern Hemisphere in the future for assessment of groundwater dynamics and volumes, after further decline of nuclear weapons test tritium there, and after analytical techniques have been improved to provide better measurement accuracy for age interpretation (Morgenstern and Taylor, 2009).

\section{Water dating}

Dating of groundwater relies on the measurement of tracer substances that have time-dependent input functions into the groundwater system or well-defined decay terms (e.g., radioactive decay). Tritium (along with oxygen-18 and deuterium) is the most direct dating tool for groundwater because as a hydrogen isotope it is part of the water molecule, and ages include the travel time through the unsaturated zone. For streamwater dating, tritium with its half-life of 12.32 years and characteristic pulse-shaped input from nuclear weapons testing six decades ago can be used for dating water with mean transit times ranging from one year to several hundred years, while methods using the variations of stable isotopes and chemicals are more suitable for younger water of $<3$ years. The latter methods are likely to truncate the age distributions and not show older water (Stewart et al., 2010). Gas tracers such as helium-3, chlorofluorocarbons, and sulphur hexafluoride equilibrate with air once groundwaters have entered the stream and thus have very limited use for streamwater dating. For improved understanding of older water components beyond the tritium method with mean transit times of up to 1000 years, silicon32 , another non-gaseous tracer, has potential for dating of water within various types of aquifer if the exchange processes of the silica in the groundwater with the aquifer material can be better understood (Morgenstern et al., 1995, 1996; Fifield and Morgenstern, 2009).

Major ion concentrations, which are easier to measure than tritium concentrations, have the potential to complement tritium dating, and help us understand the groundwater dynamics (Morgenstern et al., 2004; Daughney et al., 2010). Major ion concentrations increase with groundwater age due to mineral dissolution during water-rock interactions. In several previous investigations major ion concentrations were found to increase with groundwater age (Edmunds and Smedley, 2000; Katz et al., 2004; Zuber et al., 2005), although the relationships between groundwater age and ion concentrations can be complicated. In several studies of New Zealand catchments, we found reasonably good correlations between mean residence time of the water in the groundwater system and silica concentration of the water (Morgenstern et al., 2004, 2009). Therefore we tested if silica concentration in stream water is sufficiently correlated to water transit time to be used as a proxy for tritium age.

Tritium dating over the past decades has been problematic because the year-by-year decrease in atmospheric ${ }^{3} \mathrm{H}$ concentration occurred at a rate similar to that of radioactive ${ }^{3} \mathrm{H}$ decay. Figure 1 shows representative tritium records for precipitation in the Northern and Southern Hemispheres, together with lines showing radioactive decay of a water sample infiltrated in 1980. The nuclear-test tritium in the atmosphere steadily declined due to the combined effect of removal of ${ }^{3} \mathrm{H}$ by rain and radioactive decay of ${ }^{3} \mathrm{H}$. The similarity in the slope of the decline of tritium in precipitation to the decrease due to radioactive decay of ${ }^{3} \mathrm{H}$ caused waters with different transit times to have the same ${ }^{3} \mathrm{H}$ concentration, leading to ambiguous age interpretations that needed tritium time series data for resolution of unique ages.

That atmospheric nuclear weapons tests tritium was mostly released in the Northern Hemisphere. Only about 5\% of it mixed via the stratospheric circulation into the Southern Hemisphere. The nuclear-test tritium has now, more than four decades after levels of atmospheric tritium spiked from nuclear weapons testing during the 1950s and 60s, in New Zealand decayed to insignificant levels far below the natural cosmogenic tritium level. Recent rain water now has a higher ${ }^{3} \mathrm{H}$ concentration than water recharged during the nuclear-weapons-testing period (decay lines in Fig. 1 now fall below levels in recent rain). In the Southern Hemisphere this has occurred for about the last fifteen years, while for 


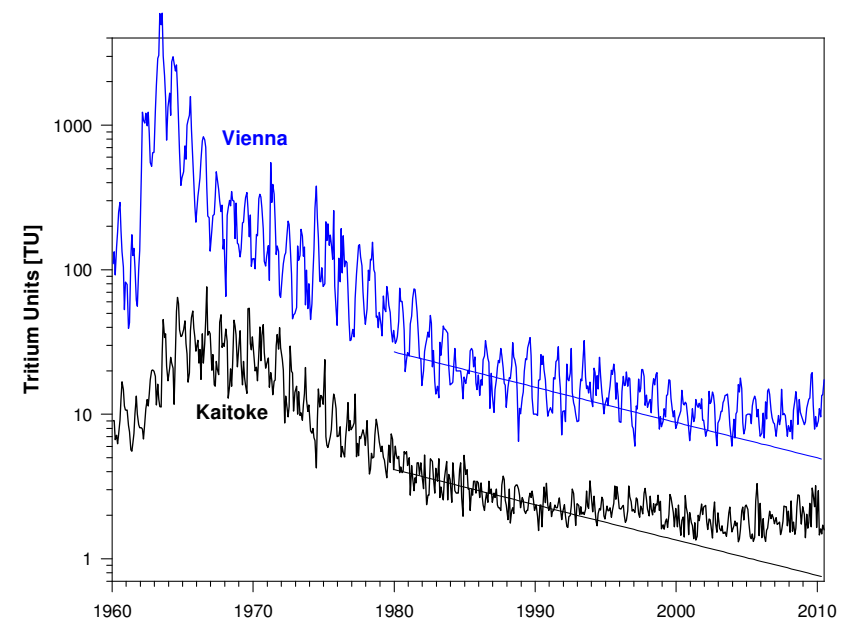

Fig. 1. Tritium in precipitation. The rain record for the Southern Hemisphere is from Kaitoke, New Zealand, and that for the Northern Hemisphere is from Vienna, Austria. Data for Vienna are from Global Network of Isotopes in Precipitation (GNIP), with data for recent years from Manfred Groening, IAEA (personal communication, 2009). One TU corresponds to an atomic ratio of tritium/total hydrogen of $10^{-18}$, and a tritium concentration of $0.11919 \mathrm{~Bq} / \mathrm{kg}$ (Morgenstern and Taylor, 2009).

the Northern Hemisphere it has occurred for about five years. There is now a difference in tritium signature between young and old water, thus allowing young and older groundwater to be distinguished. The situation will improve over time with further decay of the remaining nuclear test tritium, so that tritium can be used in a straightforward way for groundwater dating.

Figure 2 shows the respective tritium output curves versus mean residence time for Kaitoke and Vienna. In New Zealand there is already a monotonous decrease of the ${ }^{3} \mathrm{H}$ concentration with mean residence time observed because of the much lower bomb-test ${ }^{3} \mathrm{H}$ input to the Southern Hemisphere. This steady decrease, together with the high measurement accuracy of our ${ }^{3} \mathrm{H}$ measurements in New Zealand (horizontal line with broken lines show one-sigma measurement error, Morgenstern and Taylor, 2009), allows a dating accuracy of 1-3 years with single tritium measurements, even though the ${ }^{3} \mathrm{H}$ concentrations in hydrologic systems in the Southern Hemisphere are much smaller than those in the Northern Hemisphere and require more sensitive and accurate measurements. The predicted ${ }^{3} \mathrm{H}$ output for Northern Hemisphere hydrologic systems will also start to have a steady gradient similar to the current situation in the Southern Hemisphere in about ten years (Stewart et al., 2010).

Tritium dating of ground- and streamwater in the Southern Hemisphere now relies on the measured radioactive decay of cosmogenic ${ }^{3} \mathrm{H}$ occurring in the groundwater system that feeds the stream baseflow. The groundwater dating method is described in Sect. 4. Relying on the radioactive decay, ${ }^{3} \mathrm{H}$

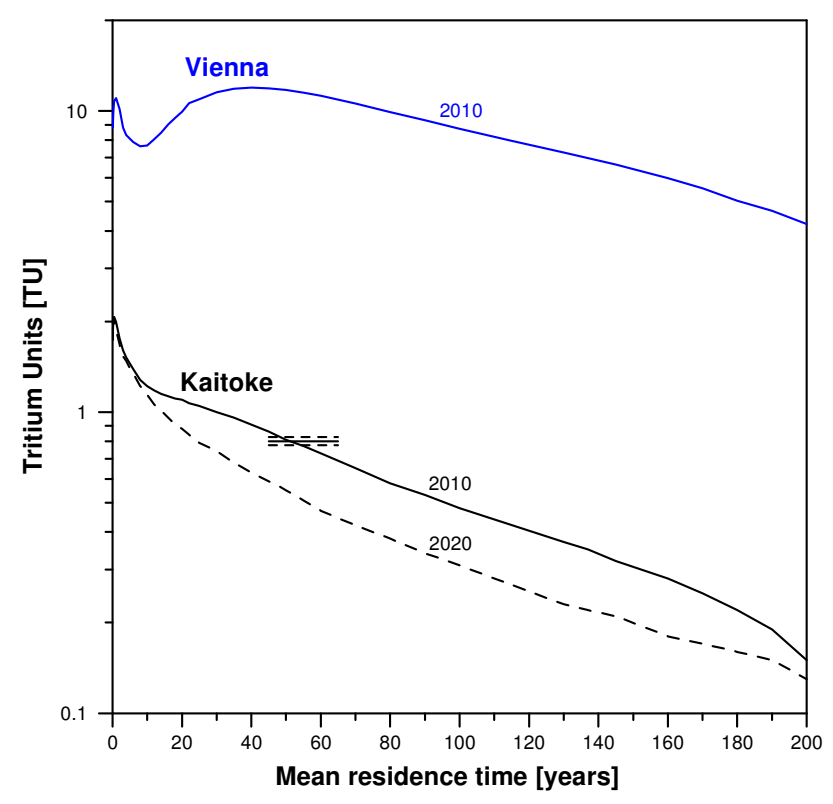

Fig. 2. Tritium output for a typical transfer function of $80 \%$ exponential flow within an exponential piston flow model for the Kaitoke (New Zealand) and Vienna (Europe) tritium inputs. Solid lines are current tritium outputs for the year 2010. The predicted output for Kaitoke for 2020 (dashed line) is shown for comparison.

dating of streamwater in the Southern Hemisphere is now possible using a single ${ }^{3} \mathrm{H}$ measurement for each individual flow rate, allowing relatively easy measurement of mean transit times across a range of flow rates.

In the Northern Hemisphere, ${ }^{3} \mathrm{H}$ dating of streamwater still requires comparison of the measured ${ }^{3} \mathrm{H}$ concentration in the baseflow groundwater discharge to the ${ }^{3} \mathrm{H}$ pulse from the atmospheric nuclear weapons testing period because ${ }^{3} \mathrm{H}$ concentrations are still affected by the tail-end of the bomb pulse. Therefore, several ${ }^{3} \mathrm{H}$ measurements in the stream are still necessary to overcome ambiguous interpretations. Mean transit times for various flow scenarios can also be determined in the Northern Hemisphere already if several ${ }^{3} \mathrm{H}$ measurements are available at each flow scenario (e.g. summer low-flow, summer baseflow, winter baseflow).

\section{Site description and catchment characteristics}

The Toenepi catchment $\left(15.1 \mathrm{~km}^{2}\right)$ is situated in a dairy farming area near Morrinsville, Waikato, North Island of New Zealand. Detailed catchment characteristics are given in Stenger et al. (2008). The elevation of the catchment ranges from approximately 40 to $130 \mathrm{~m}$ above mean sea level, reflecting the transition from alluvial plains to rolling downlands. Mean annual rainfall is approximately $1280 \mathrm{~mm}$ and mean annual air temperature is $14^{\circ} \mathrm{C}$. 

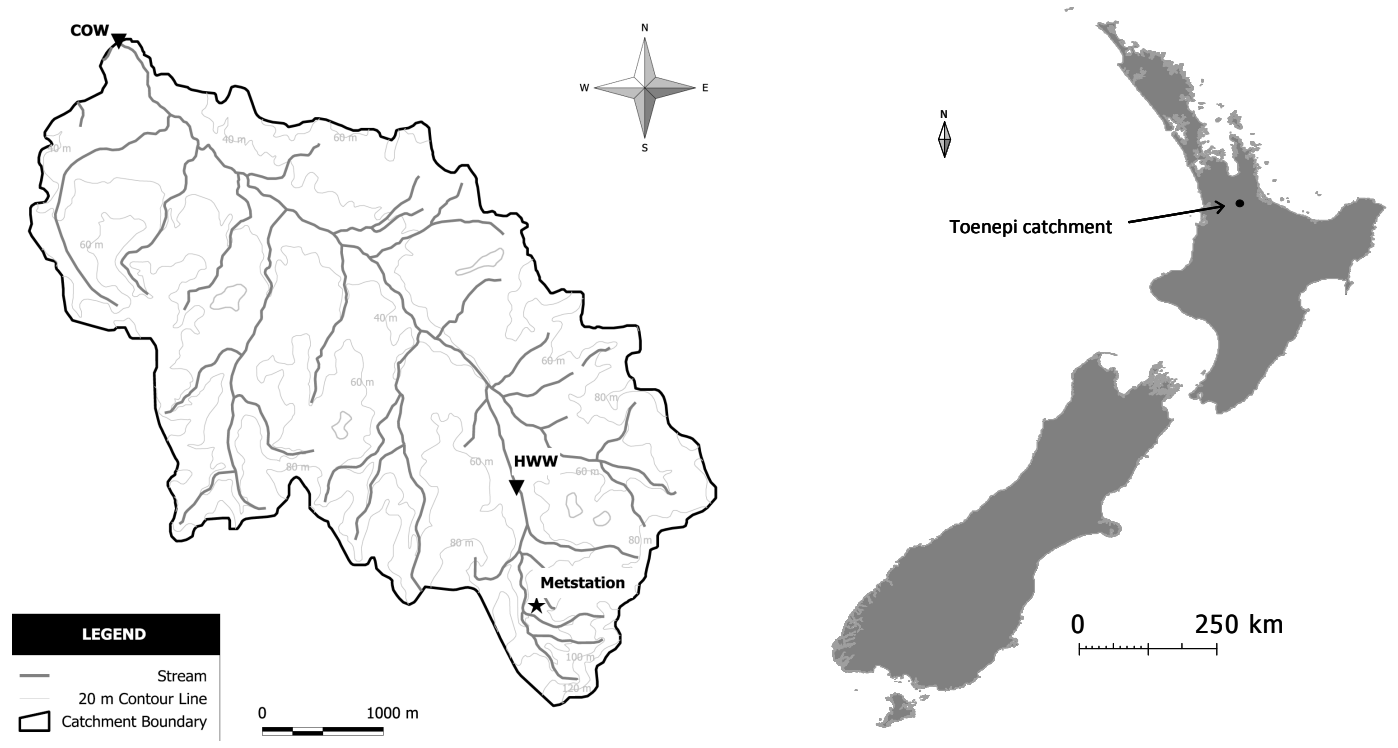

Fig. 3. Map showing Toenepi catchment boundary, 20-m contour lines, and stream sampling sites at the catchment outlet weir (COW) and headwater weir (HWW).

The alluvial plains have developed on Pleistocene rhyolitic alluvium with a varying thin cover of Holocene rhyolitic and andesitic volcanic ash. The downlands are characterised by 1-2 $\mathrm{m}$ thick Holocene to late Pleistocene volcanic ash beds of silt loam to fine sandy loam texture, overlying older strongly argillised Pleistocene ash beds (Wilson, 1980).

Streamflow was recorded and water samples for silica and tritium analyses were taken at the catchment outflow weir maintained by New Zealand's National Institute of Water and Atmospheric Research (NIWA), and at the headwater weir maintained by Lincoln Ventures Ltd. The headwater subcatchment has an area of $1.6 \mathrm{~km}^{2}$ and the headwater weir site is located approximately $5.5 \mathrm{~km}$ upstream of the catchment outflow weir site (Fig. 3).

\section{Age interpretation and mean transit time}

Groundwater at its discharge point is a mixture of water from short and long flowlines, and therefore has a distribution of ages rather than a single age. Various transfer functions describe the distribution of ages within the water sample (Maloszewski and Zuber, 1982, 1991; Goode, 1996; Weissman et al., 2002; Zuber et al., 2005). The two most commonly employed transfer functions are the dispersion model and the exponential piston flow model (Zuber et al., 2005). The exponential piston flow model is a combination of the piston flow model, which assumes piston flow with minimal mixing of water from different flow lines at the discharge point, as might occur in a narrow confined aquifer, and the exponential model, which assumes that transit times are exponentially distributed at the groundwater discharge point, as might occur for mixing of stratified groundwater at the discharge point in unconfined aquifers. These transfer functions each have two parameters - one specifying the mean and the other the spread of transit times. The parameters are determined by convoluting the input (rainfall) tritium concentrations to simulate passage through the hydrological system in such a way as to match the output (stream) tritium concentrations.

Stenger et al. (2009) identified strong redox gradients in the groundwater underlying the well-drained soils that dominate in the Toenepi catchment. The uppermost oxidised groundwater was nitrate-bearing, while the deeper reduced groundwater was nearly devoid of nitrate. Silica concentrations increased with depth, with the greatest increases coinciding with the location of the redox boundary. This observation suggested that the reduced groundwater was markedly older than the oxidised groundwater.

The water in the stream reflects water from flow paths integrated over the whole catchment area, with a continuum of flow lengths from the points of infiltration to the stream. Therefore, we used a flow model with a continuous age distribution. While the short time-series tritium data from the Toenepi stream preclude pinpointing the flow model, we used the exponential-piston flow model for age interpretation because this model produced good matches of long-term tritium data in similar hydrogeologic situations, with data from other catchments showing that the exponential flow fraction within the total flow is significantly less than $100 \%$ (Morgenstern and Stewart, 2004; Morgenstern, 2007). Also comparison of estimates of the hydraulic flow parameters through the unsaturated zone and flow model parameters (see Sect. 8) indicates that the exponential fraction within the total flow volume is $80 \%$ or less. We tested the sensitivity of the mean transit time 


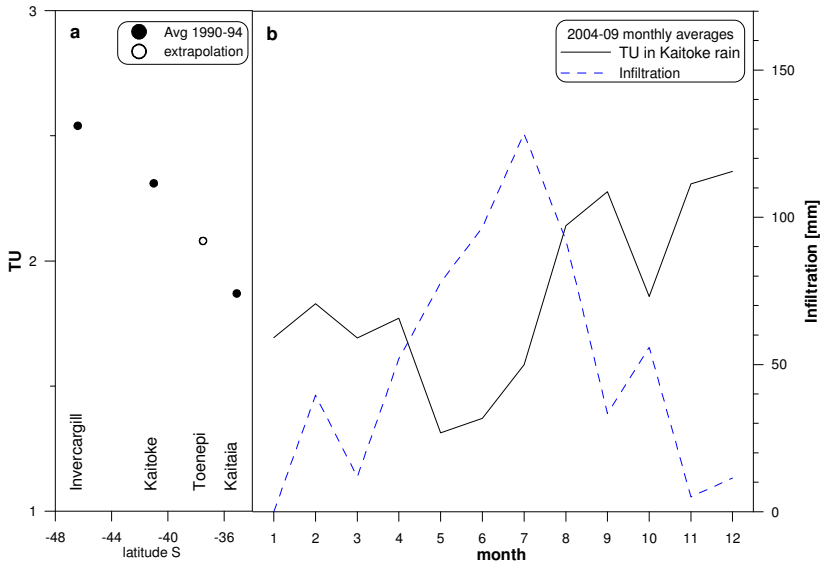

Fig. 4. (a) Average tritium concentration in rain of three reference stations (Invercargill, Kaitoke, Kaitaia) with the extrapolated value for Toenepi indicating a scaling factor of 0.9 relative to the Kaitoke reference record, and (b) monthly variation of tritium concentration and infiltration (as estimated by precipitation - potential evapotranspiration) at Toenepi. Meteorological data are from the Lincoln Ventures Ltd meteorological station in the Toenepi catchment (see Fig. 3).

(MTT) to the exponential fraction by using models with 70, 80 , and $90 \%$ fractions. For young water (MTT $\leq 5$ years), the choice of exponential fraction has relatively little effect on the mean transit time, with an insignificant difference in mean transit times of $0-0.5$ years between the three models. Also, for the medium-age water (MTT 30-40 years), the difference in mean transit time of one year for the different models is insignificant. Only for the old water (MTT $>100$ years) is there a significant difference of 15-30 years. For the Toenepi data we used an exponential-piston flow model with an exponential fraction of $80 \%$.

For the tritium input function we used the tritium record from Kaitoke near Wellington (Fig. 1), with a scaling factor 0.9 to account for the latitude of the Toenepi catchment (400 km north of Kaitoke, Fig. 4a) (Stewart and Taylor, 1981; Stewart and Morgenstern, 2001). In addition, seasonal variation can affect the tritium concentration of recharge to the subsurface. For example, evapotranspiration preferentially removes summer precipitation during the recharge process. Using climate data from the meteorological station in the Toenepi catchment (Fig. 3) through 2004-2009, we estimated the monthly infiltration as the difference between precipitation and potential evapotranspiration (Fig. 4b). Potential evapotranspiration was calculated according to FAO-56 (Allen et al., 1998). The annual tritium input concentration $C_{\text {in }}$ was then corrected by weighting the tritium concentration $C_{i}$ by the estimated average infiltration $I_{i}$ for the $i$-th month:
Table 1. Streamflow, silica and tritium concentrations, and mean transit times (MTT) for the Toenepi stream at the catchment outflow weir (COW) and at a headwater weir (HWW). Catchment outflow weir streamflow data from NIWA, headwater weir streamflow data from Lincoln Ventures Ltd. $\pm \mathrm{TU}$ is the one-sigma standard error for the measured tritium concentrations, and \pm MTT describes the MTT deviation which would still match the measured tritium concentration within its standard error.

\begin{tabular}{lllllll}
\hline Date & $\begin{array}{l}\text { Streamflow } \\
\mathrm{L} / \mathrm{s}\end{array}$ & $\begin{array}{c}\mathrm{SiO}_{2} \\
\mathrm{mg} / \mathrm{L}\end{array}$ & $\mathrm{TU}$ & \begin{tabular}{c}
$\pm \mathrm{TU}$ \\
\multicolumn{7}{c}{$\begin{array}{l}\mathrm{MTT} \\
\mathrm{y}\end{array}$}
\end{tabular} & $\begin{array}{l} \pm \mathrm{MTT} \\
\mathrm{y}\end{array}$ \\
\hline \multicolumn{7}{l}{ Toenepi catchment outflow } \\
$14 / 07 / 2004$ & 172 & 29 & 1.32 & 0.04 & 4 & 2 \\
$01 / 02 / 2005$ & 9.0 & & 1.06 & 0.05 & 34 & 2 \\
$27 / 08 / 2007$ & 240 & 22.7 & 1.40 & 0.04 & 2.5 & 1.5 \\
$25 / 01 / 2008$ & 2.5 & 55 & & & & \\
$26 / 03 / 2008$ & 1.6 & 68 & 0.265 & 0.022 & 157 & 4 \\
$24 / 04 / 2008$ & 10.1 & 54 & 0.870 & 0.035 & 39 & 2 \\
$04 / 06 / 2009$ & 52 & 37 & 1.32 & 0.04 & 4.5 & 1.5 \\
$06 / 04 / 2010$ & 3.2 & 62 & 0.466 & 0.030 & 87 & 6 \\
\hline
\end{tabular}

Weir at headwater sub-catchment HWW

\begin{tabular}{llcccll}
$14 / 07 / 2004$ & 17 & 25 & 1.32 & 0.04 & 4 & 2 \\
$01 / 02 / 2005$ & 0.87 & & 1.41 & 0.04 & 2 & 1 \\
$27 / 08 / 2007$ & 21.4 & 25.6 & 1.48 & 0.04 & 1.5 & 1 \\
$25 / 01 / 2008$ & 0.09 & 26 & & & & \\
$26 / 03 / 2008$ & \multicolumn{5}{c}{ stream ran dry } \\
$24 / 04 / 2008$ & 0.51 & 32 & 1.27 & 0.04 & 5 & 1 \\
$04 / 06 / 2009$ & 3.4 & 30 & 1.45 & 0.04 & 3 & 0.5 \\
$31 / 03 / 2010$ & 0.20 & 27 & 1.28 & 0.04 & 5.5 & 1 \\
\hline
\end{tabular}

$C_{\mathrm{in}}=\frac{\sum_{i=1}^{12} C_{i} \cdot I_{i}}{\sum_{i=1}^{12} I_{i}}$

The change in tritium input is insignificant, the average annual tritium concentration of rain and the corrected tritium input concentration are shown in Fig. 5c for comparison. This small difference would result in an age difference of only a few months. Therefore, uncertainties in the input correction process have an insignificant effect on the dating result and further refinement of the infiltration estimate is not necessary in these climatic conditions.

\section{Results and discussion}

Table 1 lists streamflow, silica and tritium concentrations, and mean transit times for the water samples from Toenepi Stream at the catchment outflow weir and the headwater weir. The samples were collected during baseflow conditions, with summer baseflows being generally much lower than winter baseflows (Figs. 5a and 7a). In particular, the January and March 2008 samples were collected at extremely low flow 

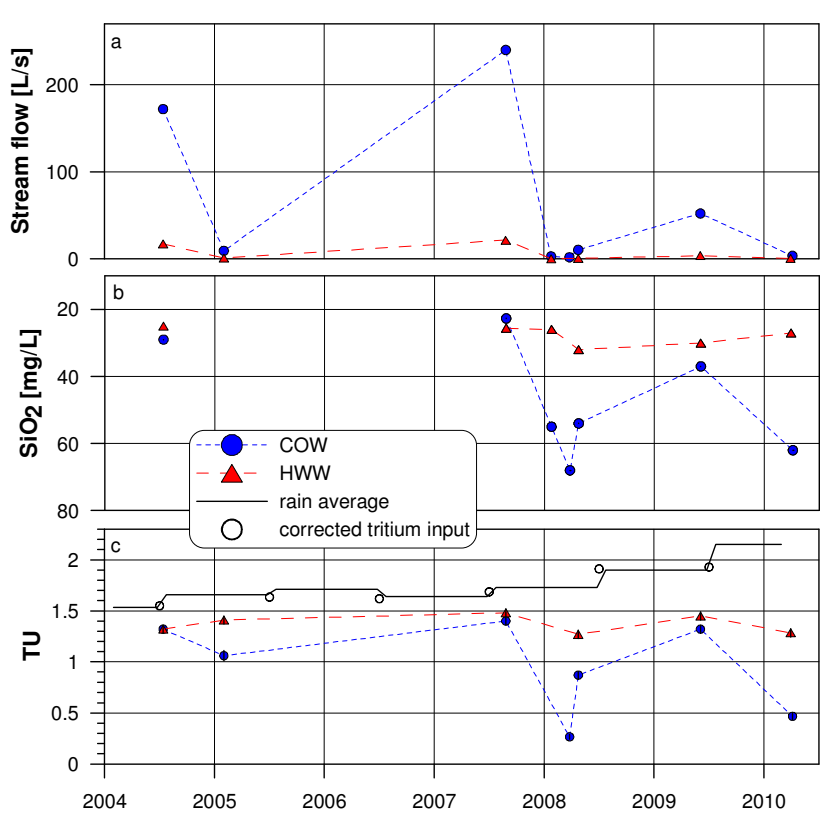

Fig. 5. (a) Streamflow, (b) $\mathrm{SiO}_{2}$, and (c) tritium concentration versus time at the catchment outlet weir (COW) and headwater weir (HWW). Note the inverse axis for $\mathrm{SiO}_{2}$. Graph c shows, for comparison, the average tritium concentrations in rain (Kaitoke data scaled by a factor 0.9 to account for the lower latitude at Toenepi, see Fig. 4a), and the corrected annual tritium input. The currently rising tritium concentration in rain is caused by variation in cosmogenic tritium production, which is modulated by cosmic rays and reflects varying solar activity.

(drought) conditions. No sample could be collected from the headwater weir sampling point during March 2008 because the stream at the headwater weir had almost dried up.

Figure 5 shows flow, and silica and tritium concentrations over time for the catchment outflow weir and the small headwater sub-catchment weir. At reasonably high winter base flow conditions $(>100 \mathrm{~L} / \mathrm{s})$, the tritium concentration in the stream at the catchment outflow weir is slightly below that of recent rain (annual average tritium units (TU) shown as full line in Fig. 5c, together with corrected annual tritium input), indicating that at winter baseflow the stream contains mostly young water with mean transit times of between 2.5 4 years (see Table 1). It is important to note that even within the range of uncertainty, the water has a mean transit time of greater than one year at reasonably high winter flow conditions. At extreme low-flow conditions in early 2008, the tritium concentration in the stream at the catchment outflow weir decreased to below $0.3 \mathrm{TU}$, indicating discharge of very old water (MTT > 100 years). Tritium concentrations during summer and autumn with flow below $100 \mathrm{~L} / \mathrm{s}$ dropped to near or below $1 \mathrm{TU}$, indicating old water with mean transit times of 30-40 years in the stream discharge.

Tritium concentrations at the headwater catchment weir at reasonable flow conditions $(>0.6 \mathrm{~L} / \mathrm{s})$ are just below those

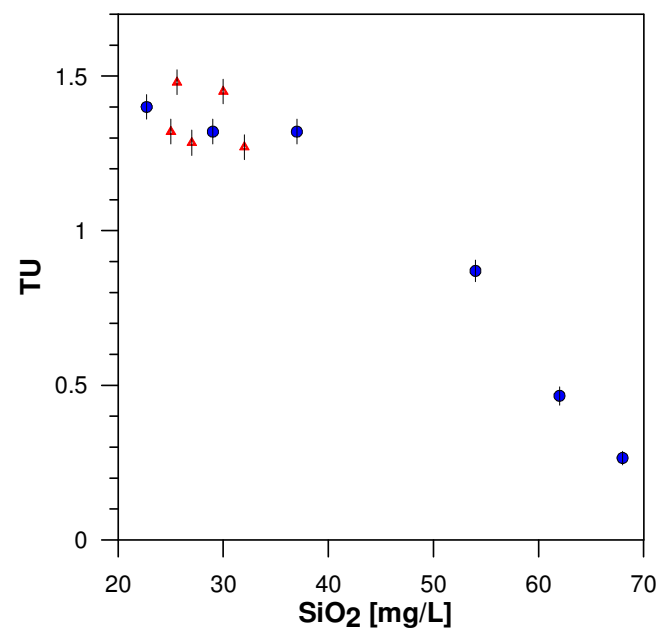

Fig. 6. Tritium versus $\mathrm{SiO}_{2}$ concentration. Explanation of symbols see Fig. 5

of present-day rain, indicating young water with mean transit times of 1.5-3 years in this upper part of the catchment (Table 1). Note that the first value of 4 years in July 2004 has a slightly higher error due to remaining ambiguity in age interpretation due to declining tritium concentration in rain prior to 2004. In early 2008 and 2010, at very low flow during drought conditions, the tritium concentration at this site also decreased significantly below that of the previous rain, indicating slightly older water with a mean transit time of 5 years.

Figure 6 shows tritium concentrations versus silica. The good correlation of the raw tritium data with silica shows that silica correlates to age; the oldest water samples with the lowest tritium concentrations have significantly higher silica concentrations. The correlation of the raw tritium data with silica also shows that ambiguity in age interpretations in New Zealand has decreased because the small amount of remaining nuclear test tritium has decayed to below the natural cosmogenic tritium level for more than a decade (Fig. 1). If nuclear test tritium were still present in significant amounts similar to that of the Northern Hemisphere, all waters with mean transit times between 0 and 100 years would have a tritium concentration similar to that of present-day rain (see Fig. 2), and there would be no correlation in Fig. 6.

\section{Conceptual groundwater flow model}

Figure 7a shows streamflow versus mean transit time. The results demonstrate that the water in the stream becomes older as streamflow decreases, and is quite dramatically older at very low flow conditions.

There is an excellent correlation between mean transit time (MTT) and streamflow $(Q)$ at the catchment outflow weir:

$\operatorname{Ln}(\mathrm{MTT})=-1.16 \operatorname{Ln}(Q)+6.36, R^{2}=0.970(N=7)$ 

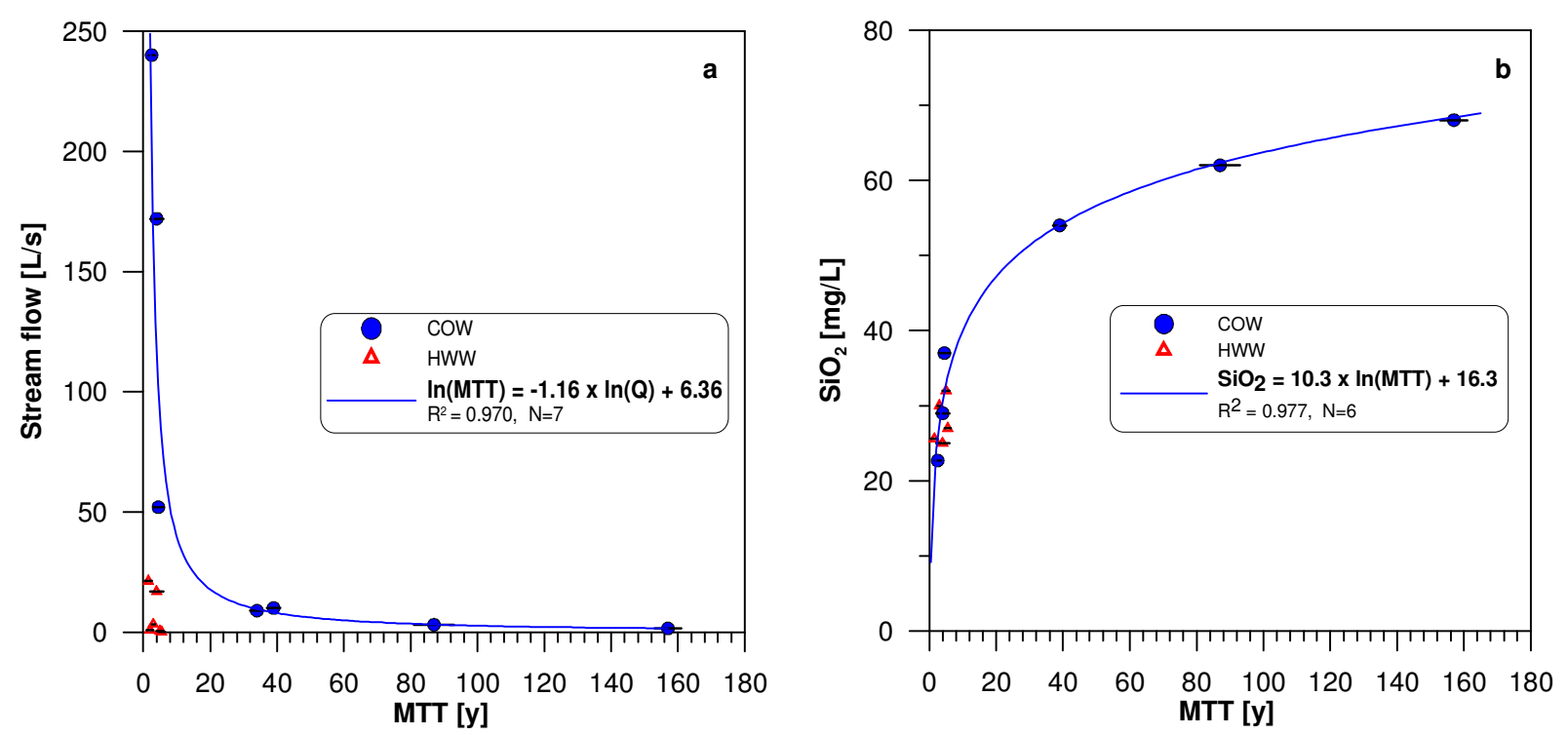

Fig. 7. (a) Streamflow and (b) $\mathrm{SiO}_{2}$ concentration versus mean transit time (MTT). Correlations are deduced from data from the catchment outflow weir (COW) only.

At relatively high winter baseflow, mainly young water $(\mathrm{MTT}<5$ years) discharges into the stream. At significantly lower summer baseflow, mainly old groundwater (MTT > 30 years) discharges into the stream.

The data at the headwater weir also indicates the trend of older water at low flow conditions. However, the correlation is very weak because young waters with mean transit times of $\sim 0-4$ years are still nearly indistinguishable from each other.

The significantly older water at low flow conditions at the catchment outflow weir of MTT 34 and 39 years compared to the headwater catchment with water of MTT 2 and 5 years indicates that older water is gained in the lower reaches of the catchment. This finding may have been expected because in dry conditions the streams maintain their flow longer in the lower reaches. However, the ambiguity caused by remaining bomb tritium until very recently prevented the accurate determination of mean transit times with single tritium measurements necessary to substantiate the hypothesis. Detailed studies of changes of transit time of the water over time scales of decades are only now becoming possible as the influence of bomb tritium wanes.

Current catchment models commonly use stationary transfer functions, with a constant transit time distribution in the water exiting the catchment. However, the tritium data in the Toenepi Stream show clearly that the transit time distribution can change significantly with flow. This demonstrates the need to develop new catchment models that account for dynamic transit time distributions. Tritium will be a useful tracer to calibrate such models for catchments with significant components of water older than 2 years.

\section{Groundwater volume}

Groundwater volume $V$ is related to groundwater flow $Q$ and groundwater age or transit time $T$ via the following fundamental equation (e.g. Maloszewski and Zuber, 1982):

$V=Q \cdot T$

To estimate the volume of water that is stored in the groundwater reservoir and actively contributing to the baseflow, we approximate the groundwater flow by the average baseflow $Q_{\mathrm{BF}}$, and the time by the mean transit time of the water at average baseflow condition $\mathrm{MTT}_{\mathrm{BF}}$ :

$V=Q_{\mathrm{BF}} \cdot \mathrm{MTT}_{\mathrm{BF}}$

Baseflow separation was carried out using the method of Hewlett and Hibbert (1967). The baseflow and quickflow components are shown in Fig. 8a, together with rainfall. The baseflow fraction was $76 \%$, using hourly flow data during the 6-year period 2004-2009. This value is comparable with the estimates of $85 \%$ for 2003 and $71 \%$ for 2004 reported by Stenger et al. (2005) and derived using a groundwater discharge model (Bidwell, 2003). While there is a year-to-year variation, it is evident that Toenepi streamflow is dominated by groundwater discharge.

To estimate the mean transit time of the stream water at average baseflow we used the correlation between mean transit time and flow Eq. (2). All tritium samples for age determinations were collected from the stream in baseflow conditions (see Fig. 8a, crosses indicate time of tritium sampling), so the calculated mean transit times for the various flow conditions characterise the groundwater reservoir that feeds the baseflow. 


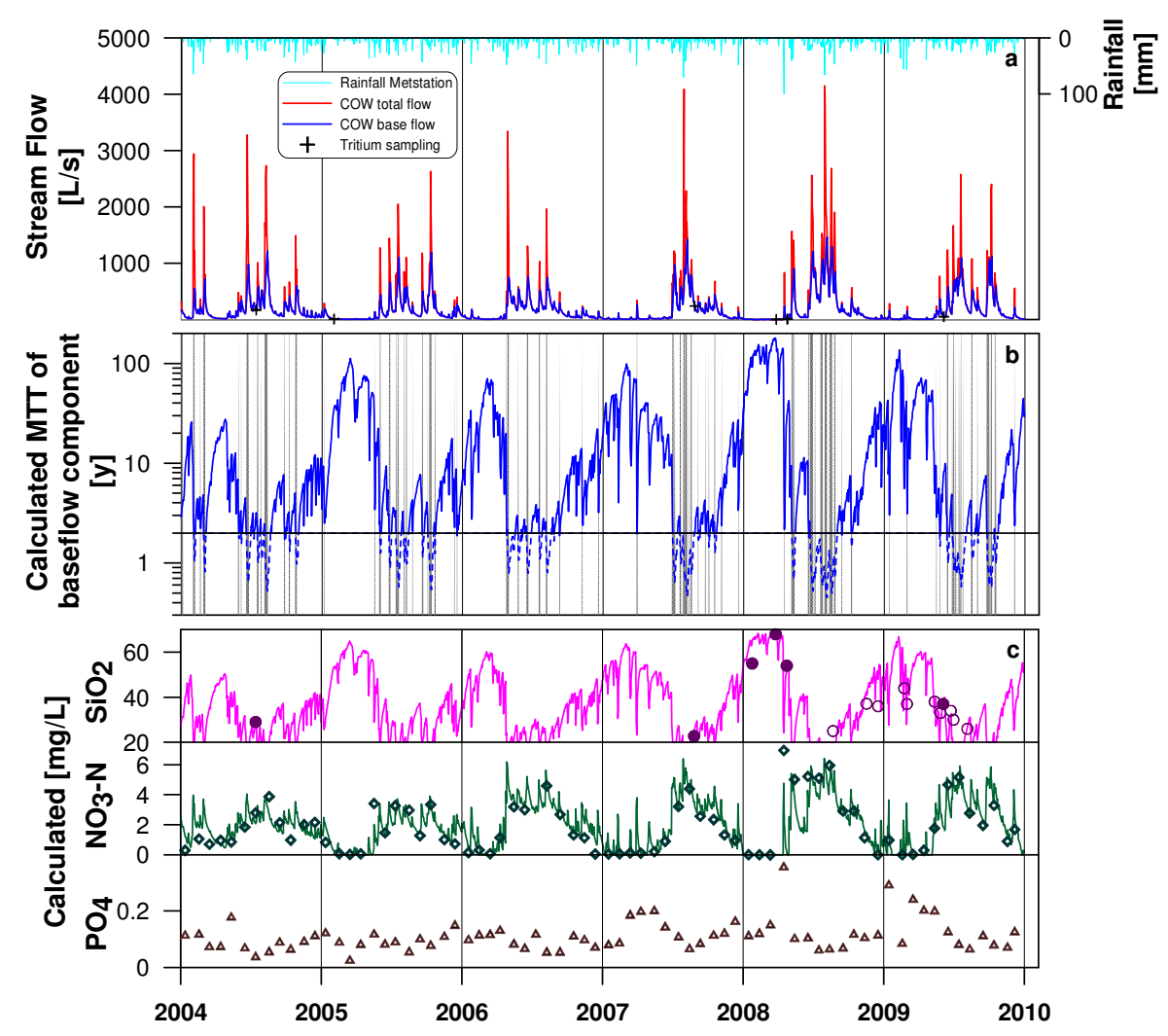

Fig. 8. Toenepi baseflow and quickflow components, together with (a) rainfall, (b) simulated mean transit time of the baseflow component, and (c) simulated (curves) and measured (points) silica, nitrate, and phosphate concentrations. Shaded areas in (b) indicate periods with quickflow run-off. Data points in (c) are measured data; full circles for $\mathrm{SiO}_{2}$ are data points with age data listed in Table 1; hollow circles are additional $\mathrm{SiO}_{2}$ data from Stenger et al. (2010), and $\mathrm{NO}_{3}$ and $\mathrm{PO}_{4}$ are data measured at the catchment outflow weir by NIWA.

Using an average baseflow of $165 \mathrm{~L} / \mathrm{s}$ and the calculated mean transit time of the water at an average baseflow of 3.0 years, we estimate the groundwater volume that contributes to the baseflow of the stream as $15.4 \times 10^{6} \mathrm{~m}^{3}$ (Table 2).

Figure 9 shows the schematic flow model ( $9 a$ and $b$ ), the parameters of the quickflow and baseflow components (9c), and the volume of the groundwater reservoir in relation to the volume of annual quickflow runoff and annual baseflow discharge (9d). The size of the boxes in Fig. 9d is proportional to the volume of the various components. Out of a total active groundwater volume of $15.4 \times 10^{6} \mathrm{~m}^{3}, 5.2 \times 10^{6} \mathrm{~m}^{3}$ are being turned over every year feeding the baseflow. The volume of quick runoff over one year $\left(1.6 \times 10^{6} \mathrm{~m}^{3}\right)$ is relatively small compared to the groundwater volume. The groundwater volume that feeds the baseflow of the stream contains about 3 times the volume of the annual baseflow, and about 2.3 times the annual total flow volume of the stream. Such a groundwater volume between the rain input and the streamflow explains the damping of the variations in the chloride concentration between rain and the stream water (e.g. Kirchner, 2003). Even at reasonably high winter baseflow, the discharging water is several years old.
Table 2. Flow components and volumes for the Toenepi stream.

\begin{tabular}{llcc}
\hline $\begin{array}{l}\text { Flow } \\
\text { component }\end{array}$ & L/s & years & $10^{6} \mathrm{~m}^{3}$ \\
\hline Total flow & $\begin{array}{l}\text { Average total flow } \\
\text { Annual total volume }\end{array}$ & 217 & 6.8 \\
\hline Quickflow & $\begin{array}{l}\text { Average quickflow } \\
\text { Annual quickflow volume }\end{array}$ & 52.0 & 1.6 \\
\hline & $\begin{array}{l}\text { Average baseflow } \\
\text { Annual baseflow volume } \\
\text { BTT at average baseflow } \\
\text { Total baseflow groundwater volume }\end{array}$ & 165 & 5.2 \\
\hline
\end{tabular}

With a catchment area of $15.1 \mathrm{~km}^{2}$, storage of water in the Toenepi groundwater is $1.02 \mathrm{~m}$ water equivalent over the catchment. This is about mid-range compared with values found in a study by Soulsby et al. (2009) for 32 Scottish catchments. They found mean transit times and storage amounts varying between 0.1 and 4.4 years and 0.3 and $2.5 \mathrm{~m}$, respectively. They noted that their longer mean transit times, which were estimated from seasonal tracer variations, will have the greater errors. 
a

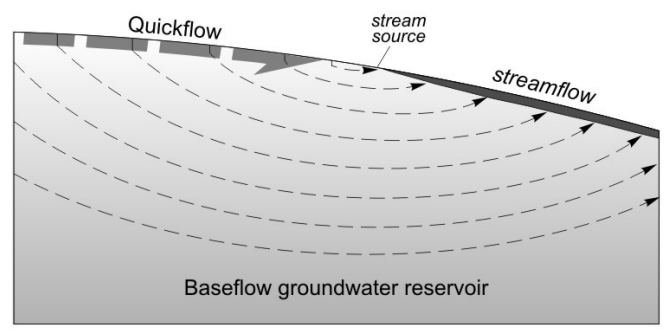

b

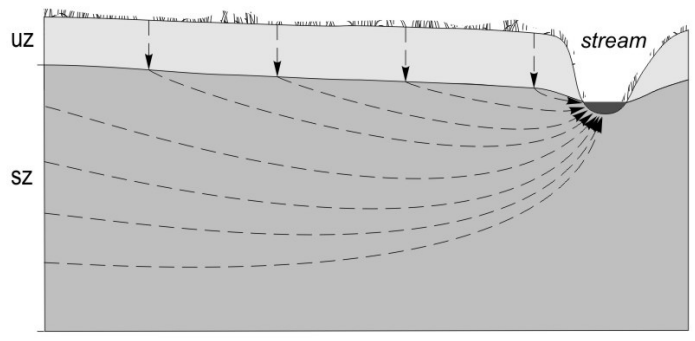

C

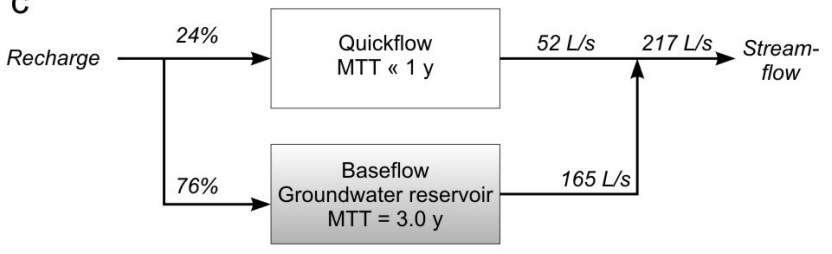

d

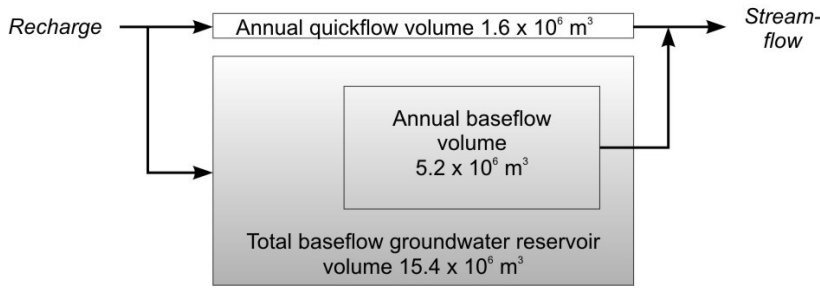

Fig. 9. Conceptual flow model (a) parallel to the stream, (b) perpendicular to the stream, UZ-unsaturated zone, SZ-saturated zone, (c) fractions of quickflow and baseflow, and (d) comparison of water volumes, with the size of the boxes proportional to the volume of the various volumes.

\section{Piston flow fraction and unsaturated zone}

Matching the measured tracer (tritium) output data via a transfer function to the known input data allows us to establish the age distribution parameters of the transfer function. It does not allow us to directly establish where in the total flow volume of the hydrologic system the various parts of the flow models apply. The fraction of transit time through the piston flow part of the total flow volume of the exponential piston flow model (EPM), however, can be calculated as $\mathrm{TT}_{\mathrm{PF}}=\mathrm{MTT} \times(1-\mathrm{f})$, with MTT the mean transit time through the total flow volume, and $\mathrm{f}$ the fraction of exponential to total flow volume. In the following we are comparing the piston flow part of the total volume with the depth of the unsaturated zone to estimate the maximum fraction of exponential flow within the EPM.

In the unsaturated zone it is commonly assumed that water percolates vertically downward and is best approximated by piston flow (PF) (Cook and Boehlke, 2000). Even though soils can be anisotropic, predominantly vertical flow can be assumed, with mixing of water limited to water parcels that entered the surface only days, weeks, or months apart. Such mixing of water of similar age in the unsaturated zone is negligible compared to the mixing in the total flow system where, for example, at the discharge point of a groundwater system, water flow lines with years, decades or longer age differences can converge.

The minimum fraction of PF within the EPM may be estimated by comparing the depth of the unsaturated zone with the flow length of PF within the EPM using the hydraulic parameters of the unsaturated zone. The flow length of the PF fraction of the EPM must be large enough to account for at least the thickness of the unsaturated zone.

The parameters for calculating the length of the PF path within the EPM $\left(L_{\mathrm{PF}}\right)$ are shown in Table 3. With the flow velocity in the unsaturated zone $\left(\mathrm{FV}_{\mathrm{UZ}}\right)$, $L_{\mathrm{PF}}=\mathrm{TT}_{\mathrm{PF}} \times \mathrm{FV}_{\mathrm{UZ}}$. At the time of minimum thickness of the unsaturated zone at high winter baseflow, the calculated $\mathrm{TT}_{\mathrm{PF}}$ at the catchment outflow weir is 0.50 years for an EPM with $80 \%$ exponential flow. With $\mathrm{FV}_{\mathrm{UZ}}$ assumed to be constant, a measured recharge of $0.45 \mathrm{~m} /$ year (annual total flow volume/catchment area), and an effective porosity of 0.16 , the calculated $\mathrm{FV}_{\mathrm{UZ}}$ is $2.8 \mathrm{~m} /$ year. The effective porosity was estimated as the weighted average of water held at 0 $1500 \mathrm{kPa}$ tension in the subsoils of three sites representing the soil types in the catchment (Stenger, unpublished). Using these values, then $\mathrm{L}_{\mathrm{PF}}=1.41 \mathrm{~m}$. This length of piston flow of $1.41 \mathrm{~m}$ is close to the average thickness of the unsaturated zone in the wet season of $1.38 \mathrm{~m}$ (weighted average of three monitoring sites representing major soil types).

A higher fraction of exponential flow within the EPM would result in $L_{\mathrm{PF}}<1.41 \mathrm{~m}$, which would result in insufficient PF length because at the very least the flow through the $1.38 \mathrm{~m}$ thick unsaturated zone would be required to be piston flow. With these assumptions, the maximum fraction of exponential flow within the total flow volume of the EPM is $80 \%$.

Clearly, the significantly larger length of PF compared to the thickness of the unsaturated zone in summer low flow conditions indicate that at least in summer considerable piston flow also occurs in the saturated zone, along parallel flow lines. $L_{\mathrm{PF}}$ would reach values of $20 \mathrm{~m}$ at summer baseflow $\left(\mathrm{TT}_{\mathrm{PF}}=7\right.$ years) and $84 \mathrm{~m}$ at summer drought conditions $\left(\mathrm{TT}_{\mathrm{PF}}=30\right.$ years) at the flow velocity of the unsaturated zone, but observations at several monitoring wells indicate that the average thickness of the unsaturated zone varies seasonally only by approximately $1.5 \mathrm{~m}$. 
Table 3. Hydraulic parameters for the Toenepi catchment at winter baseflow condition.

\begin{tabular}{lll}
\hline Transit time through the piston flow part of the total flow volume & $\mathrm{TT}_{\mathrm{PF}}=\mathrm{MTT} \times(1-f)$ & 0.50 years \\
mean transit time through the total flow volume & $\mathrm{MTT}$ & 2.5 years \\
fraction of exponential to total flow volume & $f$ & 0.8 \\
\hline Flow velocity in the UZ & $\mathrm{FV}_{\mathrm{UZ}}=\mathrm{ABV} / \mathrm{CA} / \mathrm{EP}$ & $2.8 \mathrm{~m} / \mathrm{year}$ \\
annual baseflow volume & $\mathrm{ABV}$ & $6.8 \times 10^{6} \mathrm{~m}^{3}$ \\
catchment area & $\mathrm{CA}$ & $15.1 \mathrm{~km}^{2}$ \\
effective porosity & $\mathrm{EP}$ & 0.16 \\
\hline Length of piston flow path within the EPM & $\mathrm{L}_{\mathrm{PF}}=\mathrm{TT}_{\mathrm{PF}} \times \mathrm{FV}_{\mathrm{UZ}}$ & $1.41 \mathrm{~m}$ \\
\hline Average thickness of UZ & & $1.38 \mathrm{~m}$ \\
\hline
\end{tabular}

\section{Dissolved $\mathrm{SiO}_{2}$ as a secondary age tracer}

Strong correlations of hydrochemical components with groundwater age allow the components to be used as proxies for age. This could help in understanding the dynamics of groundwater and streamflow by allowing better spatial and time resolution because chemical analyses are easier and cheaper to carry out than tritium analyses. Therefore we tested if chemical data can complement tritium data for age determination of the discharging groundwater. The $\mathrm{SiO}_{2}$ concentrations in groundwater are expected to increase with increasing time the water is in contact with the aquifer material due to evolving dissolution of silicates, and we found reasonably good correlations between water age and $\mathrm{SiO}_{2}$ concentration in various catchments in New Zealand (Morgenstern et al., 2004, 2009). Therefore, we measured $\mathrm{SiO}_{2}$ together with tritium (Table 1) in Toenepi catchment. We found an excellent correlation between $\mathrm{SiO}_{2}$ and mean transit time for the data at the catchment outflow weir site, as shown in Fig. 7b:

$\mathrm{SiO}_{2}=10.3 \times \operatorname{Ln}(\mathrm{MTT})+16.3 ; \quad R^{2}=0.977(N=6)$

The correlation coefficient $R^{2}$ close to 1 in Eq. (5) shows that there is an excellent match between the measured data and the simulated data using Eq. (5) (Fig. 8c). Such correlations with age over the range of centuries are still scarce in the literature, but will become more common in the future with further improvement of the tritium dating method.

The correlation of Eq. (5) is derived from the data of the outflow of the total catchment. The data from the headwater catchment also match this trend (Fig. 7b). Data from other catchments follow similar trends of increasing $\mathrm{SiO}_{2}$ with increasing mean transit time, however the correlation parameters are different depending on the aquifer lithologic units.

With this excellent correlation between mean transit time and $\mathrm{SiO}_{2}$, easily measured $\mathrm{SiO}_{2}$ data can be used to estimate the age of the water with a higher time resolution once the $\mathrm{SiO}_{2}$ concentration versus tritium age data is calibrated. This allows detailed study of contaminant flow paths and high-resolution time-series stream water ages for assess- ing the connection between the groundwater and the water in the stream. More detailed data on silica concentrations found in the vadose zone-aquifer-surface water continuum in the Toenepi catchment will be reported elsewhere (Stenger et al., 2010).

\section{Changing stream water quality with changing water source}

Figure $8 \mathrm{~b}$ shows the simulated mean transit time versus time using the relationship given in Eq. (2). The source of the water changes seasonally depending on the climatic water balance, with increasingly older groundwater discharging into the stream in low-flow summer conditions. Note that the simulated mean transit time in Fig. 8b represents only the transit time of the baseflow component. Mean transit time (MTT) is shown with a full line only for the parts where MTT $>2$ years; there is negligible quick flow in these flow conditions. At MTT $<2$ years there is considerable quickflow, which will make the mean transit time in the total streamflow (quick + baseflow) younger than that of the baseflow component alone. The simulated mean transit time of the baseflow component is shown as a broken line in these sections.

The chemical composition of the streamwater changes with changing water transit times. Old water, which was recharged before any contamination event or recent intensification in land use, is expected to have lower concentrations of contaminants or plant nutrients than younger water. Conversely, concentrations of compounds that are leached from the soil and aquifer material and accumulate in the groundwater (e.g. silica) are expected to be higher in the older water.

Figure $8 \mathrm{c}$ shows the simulated silica concentrations according to Eqs. (2) and (5), together with measured data. Full circles indicate the data with age measurements and that were used to establish Eq. (5), and hollow circles are additional data. The figure shows how $\mathrm{SiO}_{2}$ varies over time according to water age and flow, with higher $\mathrm{SiO}_{2}$ at times of old water discharge. 
We often found phosphate in groundwater systems, in particular aquifers with significant concentrations of hydroxyapatite, to be derived from the aquifer materials (Morgenstern et al., 2004). Therefore a relationship similar to that for $\mathrm{SiO}_{2}$ would be expected, with increasing $\mathrm{PO}_{4}$ with water age. However, the data do not show a clear correlation of $\mathrm{PO}_{4}$ to mean transit time and flow at Toenepi, because the dominant $\mathrm{P}$ source is $\mathrm{PO}_{4}$ derived from fertilisers via surface runoff rather than $\mathrm{PO}_{4}$ derived from the aquifer materials. However, the trend is visible to some extent, as the highest $\mathrm{PO}_{4}$ concentrations are observed at the lowest flows with highest mean transit times (Fig. 8c).

A reasonable correlation with flow was found for nitrate by Wilcock et al. (1998). For more recent data (Wilcock, personal communication, 2010) we found for the periods 20042005 and 2006-2010 the following correlations:

$2004-2005: \mathrm{NO}_{3}-\mathrm{N}=0.642 \times \operatorname{Ln}(Q)-1.15 ; R^{2}=0.62$

$2006-2010: \mathrm{NO}_{3}-\mathrm{N}=1.036 \times \operatorname{Ln}(Q)-2.21 ; R^{2}=0.80$

The reasonable correlation of nitrate versus flow, and indirectly mean transit time, is due to nitrate originating from pastoral land use being transported via the groundwater flow path to the stream. This contrasts with the dominant surface runoff flow path for $P$.

Figure $8 \mathrm{c}$ shows the simulated $\mathrm{NO}_{3}$ concentration in the stream (Eq. 6a and b), together with the measured data. Clearly, high $\mathrm{NO}_{3}$ concentrations occur at times of high flow with young water, while $\mathrm{NO}_{3}$ is nearly zero at low stream flow with old water. The low nitrate concentrations in the older water are likely to be a result of a combination of effects: nitrate loading in the catchment was lower several decades ago and groundwater nitrate concentrations in the Toenepi catchment are substantially affected by denitrification, particularly in the deeper groundwater (Stenger et al., 2008). Redox profiles in multi-level wells revealed that the upper, younger groundwater layer is oxidised and contains nitrate, while the deeper, reduced groundwater is nearly devoid of nitrate (Stenger et al., 2010). Knowledge of the variation of $\mathrm{NO}_{3}$ with mean transit time enables an improved understanding of the time lags and transfer of nutrients from catchments into streams to be gained.

\section{Conclusions}

Accurate tritium dating of streamwater is now possible with single tritium measurements in the post nuclear bomb pulse era in New Zealand. This enables high-resolution age dating for assessing stream water generation processes and groundwater stores.

The results demonstrate that the streamwater baseflow component has mean transit times of 2-5 years at high baseflow conditions in winter, and water becomes older as streamflow decreases, and is quite dramatically older at very low flow summer drought conditions, with ages of more than 100 years. Older groundwater is gained in the lower reaches of the stream, compared to younger groundwater in the headwater catchment.

The groundwater store was estimated from the mean transit time and flow of average baseflow to be $15.4 \times 10^{6} \mathrm{~m}^{3}$ of water, about $1 \mathrm{~m}$ water equivalent. The groundwater store that feeds the baseflow is about 2.3 times the total annual streamflow volume.

Accurate transit times of the streamwater help us to understand concentrations of contaminants that enter the stream via different pathways with different lag-times, and can explain the variation in hydrochemical composition of the streamwater as a result of the contact time of the water with the aquifer material. Nitrate, which originates from recent intensified land use and is relatively high at normal streamflow, is low at times of low flow with old water. This is likely to be a result of two effects in the Toenepi catchment, lower nitrate loading in the catchment several decades ago, and nitrate concentrations substantially affected by denitrification in the deeper more evolved groundwater. Silica that is leached from the aquifer material and accumulates in the water in proportion to contact time is high at times of low streamflow with old water.

We found a good correlation between $\mathrm{SiO}_{2}$ and groundwater age, which allows $\mathrm{SiO}_{2}$ to complement age dating and to be used to understand the dynamics of older groundwater. $\mathrm{SiO}_{2}$ is simple to sample, cheap to measure, and does not rely on variations in input for its interpretation.

This paper adds another piece of information to the search for understanding the dynamics in catchment hydrology. We show that the concentration discharge relationship is explainable by a continuum of ages in the streamwater, with higher silica concentrations at lower streamflow with older water (see Fig. 7b). The tritium data show that, even at high baseflow, the mean transit time is greater than one year (Fig. 7a), and the relevant large groundwater volumes (Fig. 9c) explain the highly damped tracer responses.

Acknowledgements. We would like to thank the anonymous referees for their very useful comments that have helped to clarify the paper, and have added interesting aspects. The work in the Toenepi catchment was funded by the Foundation for Research, Science and Technology (FRST) as part of the Groundwater Quality Protection Programme of Lincoln Ventures Ltd (8137-ASXS-LVL). We wish to thank the farmers in the catchment for their support and Aaron Wall, Juliet Clague, and Brian Moorhead for excellent technical assistance. We are grateful to Bob Wilcock (National Institute of Water and Atmospheric Research, NIWA) for providing the streamflow, nitrate, and phosphate data from the catchment outflow weir. Financial support for this study was also provided by FRST through grants to GNS Science (C05X0706, "New Zealand Groundwater Quality") and NIWA (C01X0304, "Water Quality and Quantity") via a subcontract to GNS Science.

Edited by: T. Elliot 


\section{References}

Allen, R. G., Pereira, L. S., Raes, D., and Smith, M.: Crop evaporation - Guidelines for computing crop water requirements - FAO Irrigation and drainage paper 56. FAO, Rome, 1998

Bethke, C. M. and Johnson, T. M.: Groundwater age and age dating, Annu. Rev. Earth Pl. Sc., 36, 121-152, 2008.

Bidwell, V.: Groundwater Management Tools: Analytical Procedure and Case Studies, MAF Technical Paper No: 2003/6, 2003.

Cook, P. G. and Boehlke, J. K.: Determining timescales for groundwater flow and solute transport, in: Environmental tracers in subsurface hydrology, edited by: Cook, P. G. and Herczeg, A. L., Norwell, Mass., USA, Kluwer Academic Publishers, 2000.

Daughney, C. J., Morgenstern, U., van der Raaij, R., and Reeves, R. R.: Discriminant analysis for estimation of groundwater age from hydrochemistry and well construction: Application to New Zealand aquifers, Hydrogeol. J., 18(2), 417-428, doi:10.1007/s10040-009-0479-2, 2010.

Edmunds, W. M. and Smedley, P. L.: Residence time indicators in groundwater: the East Midlands Triassic sandstone aquifer, Appl. Geochem., 15, 737-752, 2000.

Fifield, L. K. and Morgenstern, U.: Silicon-32 as a tool for dating the recent past, Quat. Geochronol., 4, 400-405, doi:10.1016/j.quageo.2008.12.006, 2009.

Goode, D. J.: Direct simulation of groundwater age, Water Resour. Res., 32, 289-296, 1996.

Hewlett, J. D. and Hibbert, A. R.: Factors affecting the response of small watersheds to precipitation in humid areas, edited by: Sopper, W. E. and Lull, H. W., in: Forest Hydrology, Oxford, Pergamon, 275-290, 1967.

Katz, B. G., Chelette, A. R., and Pratt, T. R.: Use of chemical and isotopic tracers to assess nitrate contamination and groundwater age, Woodville Karst Plain, USA, J. Hydrol., 289, 36-61, 2004.

Kirchner, J. W.: A double paradox in catchment hydrology and geochemistry, Hydrol. Process., 17, 871-874, 2003.

Maloszewski, P. and Zuber, A.: Influence of matrix diffusion and exchange reactions on radiocarbon ages in fissured carbonate aquifers, Water Resour. Res., 27, 1937-1945, 1991.

Maloszewski, P. and Zuber, A.: Determining the turnover time of groundwater systems with the aid of environmental tracers, I.: models and their applicability, J. Hydrol., 57, 22-31, 1982.

Goode, D. J.: Direct simulation of groundwater age, Water Resour. Res., 32, 289-296, 1996.

McGlynn, B. L., McDonnell, J. J., Stewart, M. K., and Seibert, J.: On the relationships between catchment scale and streamwater mean residence time, Hydrol. Process., 17(1), 175-181, 2003.

McGuire, K. J. and McDonnell, J. J.: A review and evaluation of catchment transit time modelling, J. Hydrol., 330, 543-563, 2006.

Morgenstern, U.: Lake Taupo streams - Water age distribution, fraction of landuse impacted water, and future nitrogen load, GNS Science Consultancy Report 2007/150, http://tinyurl.com/ TR2007-26, 2007.

Morgenstern, U., Brown, L. J., Begg, J., Daughney, C., and Davidson, P.: Linkwater catchment groundwater residence time, flow pattern, and hydrochemistry trends, GNS Science report 2009/08, 47 pp., 2009.

Morgenstern, U., Gellermann, R., Hebert, D., Börner, I., Stolz, W., Vaikmae, R., Rajamae, R., and Putnik, H.: ${ }^{32} \mathrm{Si}$ in Limestone Aquifers, Chem. Geol., 120, 127-134, 1995.
Morgenstern, U., Reeves, R., Daughney, C., Cameron, S., and Gordon, D.: Groundwater age and Chemistry, and Future Nutrient Load for Selected Rotorua Lakes Catchments, Institute of Geological \& Nuclear Sciences science report 2004/31, 74 pp., 2004.

Morgenstern, U. and Stewart, M. K.: Stream water dating and future nutrient load to Lake Taupo, NZ, International Workshop on the Application of Isotope Techniques in Hydrological and Environmental Studies, UNESCO, Paris, 6-8 September, 173-174, 2004.

Morgenstern, U. and Taylor, C. B.: Ultra Low-level tritium measurement using electrolytic enrichment and LSC, Isot. Environ. Healt. S., 45, 96-117, 2009.

Morgenstern, U., Taylor, C. B., Parrat, Y., Gäggeler, H. W., and Eichler, B.: ${ }^{32} \mathrm{Si}$ in precipitation: Evaluation of temporal and spatial variation and as dating tool for glacial ice, Earth Planet. Sc. Lett., 144, 289-296, 1996.

Soulsby, C., Tetzlaff, D., and Hrachowitz, M.: Tracers and transit times: windows for viewing catchment scale storage?, Hydrol. Process., 23, 3503-3507, 2009.

Stenger, R., Barkle, G., Bidwell, V., Burgess, C., Wall, A., Haas, M., and Mertens, J.: From the Paddock to the Stream - Unravelling the Nitrogen Flowpaths in a New Zealand Dairying Catchment, Proceedings of the 2005 Watershed Management Conference "Managing Watersheds for Human and Natural Impacts: Engineering, Ecological, and Economic Challenges" (19-22 July 2005), Williamsburg, Virginia, edited by: Moglen, G., Environmental and Water Resources Institute (EWRI) of the American Society of Civil Engineers, 10 pp., 2005.

Stenger, R., Barkle, G. F., Burgess, C., Wall, A., and Clague, J.: Low nitrate contamination of shallow groundwater in spite of intensive dairying: the effect of reducing conditions in the vadose zone - aquifer continuum, J Hydrol. (N.Z.), 47(1), 1-24, 2008.

Stenger, R., Bidwell, V., Wall, A., Clague, J., and Moorhead, B.: Nitrogen contamination of surface waters: What are the important flowpaths in the Toenepi dairying catchment?, Lincoln Ventures Ltd Progress Report 3653/3, September 2009, http://www.lvl.co.nz, 2009.

Stenger, R., Woodward, S., Bidwell, V., Clague, J., and Wall, A.: Groundwater dynamics and redox-stratification determining seasonally and annually varying nitrate discharge into a lowland stream, in preparation, 2010.

Stewart, M. K. and Fahey, B. D.: Runoff generating processes in adjacent tussock grassland and pine plantation catchments as indicated by mean transit time estimation using tritium, Hydrol. Earth Syst. Sci., 14, 1021-1032, doi:10.5194/hess-14-10212010, 2010.

Stewart, M. K., Mehlhorn, J., and Elliott, S.: Hydrometric and natural tracer $\left({ }^{18} \mathrm{O}\right.$, silica, ${ }^{3} \mathrm{H}$ and $\left.\mathrm{SF}_{6}\right)$ evidence for a dominant groundwater contribution to Pukemanga Stream, New Zealand. Hydrol. Process., 21(24), 3340-3356, 2007.

Stewart, M. K. and Morgenstern, U.: Age and source of groundwater from isotope tracers, in Groundwaters of New Zealand, edited by: Rosen, M. R. and White, P. A., New Zealand Hydrological Society Inc., Wellington, 161-183, 2001.

Stewart, M. K., Morgenstern, U., and McDonnell, J. J.: Truncation of stream residence time: How the use of stable isotopes has skewed our concept of streamwater age and origin, Hydrol. Process., 24, doi:10.1002/hyp.7576, in press, 2010.

Stewart, M. K. and Taylor, C. B.: Environmental isotopes in New 
Zealand hydrology. Part 1. Introduction: The role of oxygen-18, deuterium and tritium in hydrology, New Zeal. J. Sci., 24, 295 311,1981

Weissman, G. S., Zhang, Y., LaBolle, E. M., and Fogg, G. E.: Dispersion of groundwater age in an alluvial aquifer. Water Resour. Res., 38, 16.1-16.8, 2002.

Wilcock, R. J., Rodda, H. J. E., Scarsbrook, M. R., et al.: The Influence of Dairying on the Freshwater Environment (The Toenepi Study), NIWA Client Report DRI60202, 1998.
Wilson, A. D.: Soils of Piako County, North Island, New Zealand, New Zealand Soil Bureau, 1980.

Zuber, A., Witczak, S., Rózañski, K., Śliwka, I., Opoka, M., Mochalski, P., Kuc, T., Karlikowska, J., Kania, J., JackowiczKorczyński, M., Duliñski, M.: Groundwater dating with $3 \mathrm{H}$ and SF6 in relation to mixing patterns, transport modelling and hydrochemistry, Hydrol. Process., 19, 2247-2275, 2005. 